\title{
Explaining Interest Group Interactions with Party Group Members in the European Parliament: Dominant Party Groups and Coalition Formation
}

\author{
David Marshall \\ Politikwissenschaft \\ Universität Salzburg \\ Email: davidjohn.marshall@sbg.ac.at
}

\begin{abstract}
This article develops and tests a theory of party group lobbying which demonstrates how the European Parliament's decision-making process shapes interest group interactions with legislators. Interest group behaviour is highly conditional on two motivations: (1) lobby powerful MEPs, and (2) lobby friendly MEPs. Friendliness is based on ideology, with power shaped by institutional rules and seat share. These goals can mutually reinforce each other. However, because these two motivations exist, and because political power is not fully predictable, there are strong incentives for interest groups to lobby party groups that are nonnatural allies to ensure that their policy information reaches the winning side. But, when interest groups engage in this behaviour, they retain their preference to lobby the friendliest members. The analysis is carried out on 9 policy-related categories of interest group, with MEP data from 3 parliaments (1999-2011) combined with information on the parliamentary role of 724 respondents.
\end{abstract}

Keywords: Interest Groups, European Parliament, Party Groups, Decision-making, Lobbying

* I would like to express my thanks to Kenneth Benoit, Patrick Bernhagen, Andreas Dür, Anne Rasmussen, Mike Seiferling, Markus Wagner and two anonymous reviewers. 


\section{Introduction}

A great deal is now known about the incentive structure through which interest groups decide which Members of the European Parliament (MEPs) to lobby (Kohler-Koch, 1998; Wessels, 1999; Bouwen, 2004; Eising, 2007; Mahoney, 2008; Marshall, 2010). Yet, scant attention has been given to assessing the role that European party group membership may play in this strategic choice, even though it is widely acknowledged that party groups are central to decision-making in the European Parliament (EP) (Attinà, 1990; Hix and Lord, 1997; Raunio, 1997; Hix et al, 2006). The reason for this lack of interest may simply be that the explanation is considered self-evident. After all, it is more or less accepted that interest groups have a strong preference to lobby their friends (Baumgartner and Leech, 1996; Kollman, 1997; Hojnacki and Kimball, 1998), which in the EP translates to seeking advocacy from ideologically congruent political parties (Wessels, 1999). Indeed, these preferences underpin the main argument of the paper.

However, in apparent contradiction, I suggest that interest groups frequently lobby MEPs belonging to the least congruent large party groups. This is because within the EP interest groups have a strong incentive to make certain that their policy position is registered with more than one of the ideologically distinct dominant party families: uncertainty about which parties will form a winning coalition on any given legislative issue means that failing to lobby unfriendly MEPs creates the risk that an interest group's message will go unheard at the negotiating table.

The extent to which organised interests deviate from the 'lobbying friends' strategy is a function of the EP institutional arrangements. It is the EP's rules of procedure that position European party groups at the centre of the political web and in particular privilege the largest party families. With no permanent voting majority in any parliamentary term, decision- 
making has so far always been contingent on the formation of several possible winning coalitions, each of which must contain at least two of the three largest political groups

But, in addition to highlighting the limitation to the 'lobbying your friends' thesis an explanation is provided for its resilience. It is anticipated that when the strategic decision is taken to lobby members of a relatively unfriendly party group, interest groups' revert to the practice of discriminating on the basis of policy preferences, but in this instance within the population of least aligned large party group members. As such, they choose to lobby the most sympathetic members from amongst this otherwise off-limits party.

In principle these theoretical expectations are compatible with much of what we already know about the relative influence of MEPs and lobbying in the EP. As such, and in order to facilitate a unified understanding, certain key findings from the literature will be analysed alongside the central argument. These include the assumption that interest groups overwhelmingly lobby MEPs that are members of a germane committee (Bowen, 2004). This is important to establish because such behaviour would be entirely consistent with the policyseeking motivation that the theory ascribes to interest groups, and as such would necessarily extend the theoretical reach to within the committee system. These ideas are also consistent with the underlying assumption that disparities in legislative influence between MEPs provide a strong incentive for interest groups to modify their strategic behaviour. Therefore it seems appropriate to incorporate into the analysis the insight that legislative influence is also positively correlated with individuals' level of engagement with the legislative process (Kreppel, 2002; Yoshinaka et al, 2010).

These ideas are examined through several sources of information, including responses by MEPs to surveys carried out by the European Parliamentary Research Group (EPRG) during the $5^{\text {th }}, 6^{\text {th }}$ and $7^{\text {th }}$ parliaments (Farrell et al, 2011); parliamentary data on the activities of the 724 MEPs that responded to the surveys; and responses received from interest groups. 
The starting point for the analysis was selected to coincide with the point that the EP can unambiguously be described as a co-legislature alongside the Council, following the reform and extension of the co-decision procedure (Crombez, 2001).

The following section of the paper synthesises key insights about the role of European party groups, national parties, the EP's committee system, and the literature explaining the pattern and causal mechanism of organised interests' interactions with MEPs. Together this investigation underpins the theoretical expectations and testable hypotheses presented in the second section. The methodological approach is set out in the third, including a clear explanation of the variables later used. Thereafter, the results are presented followed by a concluding assessment of the significance of party membership on lobbying behaviour.

\section{Literature}

European party groups play a vital role in structuring political debate and coalition formation within the EP (Hix and Lord, 1997; Kreppel, 2002); with the rules of procedure facilitating this outcome. What is more, although national party loyalties are likely to take precedence when in conflict with the party group (Ringe, 2010), these occasions are now far from the norm (Hix and Noury, 2009). This increased tendency for party groups to vote en bloc appears to be a consequence of the growth in the EP's institutional power rather than as a function of ideological congruence (Raunio, 1997; Hix et al, 2007). Each new treaty since the implementation of the Single European Act (1987) has given the EP more power, which has led party groups to increase the incentives for their members to adhere to the party whip.

The inclusion of at least two of the three largest political groups, i.e. the European Peoples Party (EPP), the Party of European Socialists (PES), ${ }^{1}$ or the Alliance of Liberals and Democrats for Europe (ALDE), is essential for a winning coalition to form. This is because to

\footnotetext{
${ }^{1}$ In the $7^{\text {th }}$ parliament the Party of European Socialists became the Progressive Alliance of Socialists and Democrats. For simplicity the PES/S\&D group will be referred to as simply the PES.
} 
date no party has secured a majority of seats, and with no government to support there is no necessity for permanent coalitions to be formed. Although in the past there was a tendency for 'grand coalitions' to form between the PES and the EPP, these have become less common since the early $1990 \mathrm{~s}$, and by the $6^{\text {th }}$ parliament the two largest parties voted independently with the liberals more often than they did with each other (Hix and Høyland, 2011). This trend was aided by the rapid increase in first reading co-decision agreements, made possible under the Treaty of Amsterdam (1999), which do away with the necessity to form oversize majorities.

The effect has been to facilitate de facto legislative agreements between EP committees and the Council prior to the first reading in plenary, thereby privileging committees (Farrell and Héritier, 2003; Häge and Kaeding, 2007) and in particular the rapporteurs (Héritier, 2007; Costello and Thompson, 2010). As such, the EP's interinstitutional negotiating position invariably reflects the policy agreed within committee, which is reached through a simple majority of attending members. This delegation of power by the plenary to its legislative committees is only possible because EP committees conform to the formal requirement that they 'reflect the composition of Parliament' (Rule 177; 2010), which includes party group membership (McElroy, 2006; Yordanova, 2009).

The institutional framework is constructed in such a way that for a committee member to exert particular legislative influence, sustained engagement with the policy process is required (Marshall, 2010). This relationship is reflected in the allocation of Committee reports, where MEPs' relative level of voting activity in plenary is one of several explanatory factors (Kreppel, 2002; Yoshinaka et al, 2010). It follows that MEPs are more likely to join a committee that covers a policy area with salience to those special interests that they are already associated with (Yordanova, 2009), which makes the finding that committee 
membership makes no significant difference to the likelihood of an MEP being lobbied by business interests somewhat puzzling (Eising, 2007).

The literature makes it clear that party groups are integral to decision-making in the EP, which is concentrated within the committee structure. Yet research on interest group behaviour has largely overlooked the role of party groups. The exception is Wessels (1999) who addressed the issue through a series of two-dimensional plots showing the density of interactions between MEPs and interest groups during the pre-Amsterdam era $4^{\text {th }}$ parliament (1994-1999). He identified three broad alignments between interest groups and party groups: (1) business interests with Liberal, Christian Democrat, and Conservative party groups; (2) trade unions with Communists and Socialist party groups; and (3) environmental and consumer interests with Green and radical party groups.

Attention has been given to the question of whether it is strategically advantageous for interest groups to lobby legislators who are known to be unsympathetic to their cause. The approach taken is rooted in the Congressional literature, where this once live debate appears settled: organised interests hardly ever lobby their opponents, and only occasionally interact with those yet to decide (Baumgartner and Leech, 1996; Kollman, 1997; Hojnacki and Kimball, 1998). The underlying logic for this behaviour is provided by the signalling literature, which emphasises the importance of a lobbyist's reputation for providing good quality policy information as a means of overcoming information asymmetries (Parker, 2004). The implication is that reputations are built over time and are more likely to be fostered with likeminded policy-makers. A contrasting perspective is offered by Hall and Waymen (1990), albeit in respect to campaign contributions, in which they show that within congressional committees organised interests commit resources to both mobilise natural supporters and to discourage opposing legislators from mobilising - with the aim of altering patterns of participation rather than the remote prospect of directly securing votes. 
In the EP, through formal modelling of interest group behaviour, the applicability of the lobbying your friends' thesis has been demonstrated, at least in respect to the plenary (Crombez, 2002); a contribution that remains consistent with Wessel's earlier empirical work. But where the EP literature departs from this perspective it is in respect to the period when the rappporteur drafts her legislative report. Here the institutional constraints are such that considerable agenda setting power is concentrated in the hands of a single possibly friendly legislator. In these circumstances the allure of power trumps that of friendship, with interest groups electing to lobby rapporteurs irrespective of whether they are from a party group that supports opposing policies to their own (Marshall, 2010).

The corresponding literature encompassing interest group interactions with national parties is surprisingly limited, particularly in respect to unstructured contacts which increasingly dominate relations (Rasmussen and Lindeboom, 2013). Instead the focus has tended towards in-depth studies analysing ties between parties and closely associated interests (for example, Quinn, 2010 and Thomas, 2001), in effect drawing upon those relationships first identified by Duverger (1954) as instrumental in creating and sustaining political parties.

In contrast Allern's (2010) in-depth study of the Norwegian case illustrates that parties have links with a diverse set of societal actors rather than a chosen few. This finding corresponds to the observation that through the process of cartelisation the established relationships between political parties and civil society organisations have diminished (Katz and Mair, 1995), and arguably better approximate to the informal and fluid pattern of lobbying that occurs within the EP (Bowen, 2004). However, Allern's focus on central party structures does not capture the general shift in lobbying attention towards parliamentary groups, and as such maybe less relevant to the case of the EP. More recent research by Otjes and Rasmussen (2013) provide such parliamentary group focus. Analysing interest group ties 
in Denmark and the Netherlands they reveal the persistence of the left/right division, with groups associated with the left preferring to interact with likeminded parties and vice versa. Interesting, they find that this relationship is weaker in Denmark where governments tend to alternate between left and right.

This brief review has highlighted the increasingly decisive role that both large party groups and the committee system play in defining the EP's legislative position. Committee power, which is delegated from the plenary, is contingent on the support of a winning coalition that must include two or more of the largest party groups. Interest groups lobby members of sympathetic party groups within the EP, much as they do within national party systems. Where interest groups refrain from lobbying members of congruent political parties, the literature suggests that this maybe because there is an absence of friendly influential legislators.

\section{Explaining interest group interactions with MEPs}

Interest groups seek to influence policy outcomes. Therefore it is expected that groups will adapt their strategic behaviour to take account of the specific nature of the decisionmaking process, which includes the structure of wining coalition formation as well as other hallmarks of legislative influence. But, in the knowledge that if all things are equal it is most advantageous to lobby legislators with closely aligned interests. To maximise the explanatory power and robustly assess the theory of party group lobbying, the analysis is conducted alongside existing ideas that link legislative influence with interest groups' strategic behaviour.

\section{Coalition formation and the effect on party group lobbying}

Given the central role played by political groups in EP decision-making, it would be surprising if interest groups' lobbying decisions were party-blind. As such, the three 
dominant party groups' hold on decision-making will constrain the range of viable parties interest groups can choose to lobby. For example, interest groups which in other circumstances may not be drawn to these pro-integration centrist parties have a strategic incentive to redirect at least part of their lobbying effort to parties at the centre of coalition formation. Therefore, it is expected that:

$H_{1} . M E P s$ from the three dominant party groups are lobbied more often than members from other party families.

However, the fluid nature of winning coalition formation has an additional effect on interest groups' strategic behaviour. They intentionally engage in lobbying MEPs from the least friendly of the dominant political groups. The reason for this surprising yet theoretically consistent behaviour is that unlike most national parliaments, where voting coalitions are broadly stable and therefore known in advance, in the EP it is uncertain which party groups will be on the winning side. This creates a powerful incentive for interest groups to 'hedge their bets' and divert considerable lobbying effort away from the party group that they are naturally more associated with, to a party that is a non-natural ally. Therefore, in contrast to the expectation found in the literature we should observe that:

$H_{2}$. The frequency of MEP interactions with groups representing either civil society or producer interests will be similar for members of both the EPP and PES.

However, rather than falsifying the 'lobbying your friends' thesis, these expectations simply represent a further and more significant limitation to interest groups' unconstrained lobbying preference, i.e. in addition to lobbying unfriendly rapporteurs. This is because interest groups underlying motivation, even when constrained, continues to structure their choice of lobbying target. Therefore, when for strategic reasons interest groups lobby a party group that is not a natural ally, they revert to their unconstrained default position and lobby 
those closest to their own policy preferences, but in this case within the population of nonfriendly party members. Therefore, the expectation is that:

$H_{3}$. When interest groups attempt to influence dominant party groups that are naturally less supportive, they lobby those members with relatively close policy preferences.

\section{Towards a unified understanding: participation and committee membership}

It seems plausible to expect that interest groups' interactions with MEPs are conditional upon the latter's membership of a policy relevant committee, particularly given that the EP's policy output has become increasingly defined through the scrutiny carried out by its standing committees (Corbett et al 2011). But if committee membership turned out to be unimportant to lobbyists (Eising, 2007), it would suggest that they are not policy-seekers, thereby falsifying a key assumption of the theory as presented. In contrast, empirical support for the relationship would suggest that what holds for the theory of party group lobbying will hold within the EP's committees, which would maximise the explanatory power of the theory. As such, we should observe that:

$H_{4}$. Interest groups are more likely to lobby MEPs that are members of a policy relevant committee than non-members.

But, although committee membership may provide the opportunity to be influential, this is not to say that committee members are equally influential, and hence of equivalent interest to lobbyists. However, given that relative levels of participation in the legislative process are an important factor in determining policy influence (Kreppel, 2002; and Yoshinaka et al, 2010), and the theoretical assumptions presented thus far are predicated on interest groups' desire to lobby influential legislators, it should be the case that:

$H_{5 .}$ Interest groups are more likely to lobby MEPs that are active legislators. 


\section{The Data}

To assess the inherently unobservable phenomenon of lobbying behaviour, the analysis draws on several sources of MEP data covering three European Parliaments (1999-2004; 20042009; and 2009-14). The sample under analysis is defined by responses to three surveys of MEPs (2000, 2006, and 2010) conducted by the EPRG (Farrell et al, 2011). The number of individual observations is 724 (35\%), out of a possible 2,094 MEPs that were in office at the time the respective surveys were conducted. The sample of MEPs for each survey is comparable, and reasonably representative of the EP as a whole in terms of party group membership and nationality (Hix et al, 2011). The survey results provide self-reported information on MEPs' contacts with specific categories of interest group, on their policy opinions and on their ideological position. Information on MEPs' seniority and committee membership was obtained from Høyland et al's (2009) MEP database, with further data collected via the EP's website. In addition the analysis draws from 80 responses to a question asked by the author to 86 interest groups that are active in the EP.

The dependent variables are the number of contacts that MEPs report to have had with nine policy specific categories of interest group. There are six possible responses to this question which are initially coded in the manner adopted by Wessels (1999). Responses of 'at least once a week' are taken as 52 on an annualised basis; 'at least once a month' as 12 ; 'at least every three months' as 4 ; 'at least once a year' as 1; with both 'less often' and 'no contact' represented as $0 .^{2}$ The questionnaires asked respondents to give answers for both national and European group variants for 8 of the 9 categories. But as this distinction is outside the scope of the paper the results for these variants have been combined, allowing a

\footnotetext{
${ }^{2}$ This transformation enables the relative differences in contacts to be more fully captured . However, analysis conducted with the dependent variables left untransformed i.e. ranging 0-5 (ordered logit), yielded broadly similar results.
} 
more nuanced picture of MEPs interaction across policy sectors to emerge. ${ }^{3}$ The independent variables are as follows:

Party dummies: One each for the four largest European party groups, i.e. EPP, PES, ALDE and the Green party.

Left/Right self-placement: This measures an MEP's perception of his or her ideological position on a 10-point left/right spectrum; extreme left $=1$, and extreme right $=10{ }^{4}$

Policy opinion(s): MEPs' responses to policy questions that have a good fit to five of the nine dependent variable categories are reported. There are two distinct question formats, with the first asking MEPs if they 'think there should be more or less EU regulation in the following [two] areas': 'environmental protection standards'; and 'discrimination'. The second question type asked MEPs if they 'think there should be more or less of the EU budget spent on the following [three] areas': 'agricultural price support'; 'scientific research and development'; and 'support for refugees'. The questions allowed for five possible responses, coded 1-5; with preferences for 'a lot more' of a given policy, coded as 1; 'a little more' as 2; 'about the same' as 3; 'a little less' as 4; and 'a lot less' as 5.

Committee membership dummies: MEPs' membership of a committee is matched to a corresponding dependent variable (interest group type). But, with committee responsibilities sometimes shifting between parliaments, it has been necessary to track these changes. This means that committee descriptions refer to the enduring policy sector. For example, consumer interests were combined with Environmental policy in the $5^{\text {th }}$ parliament, but became part of IMCO in the $6^{\text {th }}$ and $7^{\text {th }}$ parliaments. Here the discussion and analysis refers to the committee with responsibility for consumer interests. This means that the categories are not exclusive, with committees generally encompassing additional policy areas. However, the direction of

\footnotetext{
${ }^{3}$ This means that there are 13 possible values that these variables can take: $0,1,4,5,12,13,16,24,52,56,64$, and 104.

${ }^{4}$ MEP responses for the $7^{\text {th }}$ Parliament are rescaled because in this instance the question adopted an 11 point scale $(1-11)$.
} 
any misalignment is such that the results presented are likely to understate the anticipated effect. The status of committee substitutes proved more problematic. This is because many of them are amongst the more prominent committee members, ${ }^{5}$ yet it appears that more commonly substitutes play a less meaningful part in committee life. To reconcile this, committee substitutes are taken to be de facto members if they have written a legislative report, thereby demonstrating a high level of engagement with the committee.

Participation: measures MEPs attendance at plenary (roll-call) voting sessions, for the appropriate parliament; it is coded between 0 and 1, with 1 indicating $100 \%$ attendance. The sample mean is $0.8(80 \%)$, whereas the population mean is $0.73(73 \%){ }^{6}$

Rapporteur: measures the number of reports written within a relevant committee in a given parliament for either the Co-decision or consultation procedures. ${ }^{7}$

Parliament Dummies: for the $6^{\text {th }}$ and $7^{\text {th }}$ parliaments.

Member State Dummies: for the four largest member states.

\section{Specification}

Each of the nine interest-specific dependent variables is first tested in one general model specification. Because the dependent variable is effectively a count of the number of times an MEP has been lobbied, the equation is fitted following a Poisson distribution of the form:

$$
\begin{gathered}
\ln \left(\widehat{y_{l j}}\right)=\alpha_{j}+\beta_{1 j} * \text { committe }_{i j}+\beta_{2 j} * \text { rapporteur }_{i j}+ \\
\beta_{3 j} * \text { participation }_{i j}+\beta_{4 j} * \text { left }_{\text {right }}+\beta_{5 j} * \beta_{5 j} \text { epp }_{i j}+
\end{gathered}
$$

\footnotetext{
${ }^{5}$ Yoshinaka et al (2010) note that for the $4^{\text {th }}$ and $5^{\text {th }}$ parliaments, $15 \%$ and $14 \%$ of all reports were assigned to committee substitutes.

${ }^{6}$ This may suggests that MEPs who turn-up less often to vote are also less likely to reply to surveys, which has implications for survey data in general.

${ }^{7}$ The Consultation procedure was included following Kardasheva's (2009) insight that the EP often exerts significant influence.
} 


$$
\begin{array}{r}
\beta_{6 j} * \text { pes }_{i j}+\beta_{7 j} * \text { alde }+\beta_{8 j} * \text { green }+\beta_{9 j} * \text { opin }_{i j}+ \\
\beta_{10 j} * \text { 6th parl } \\
i j
\end{array}
$$

For $\forall j=1, \ldots, 9$

Where: $\quad \operatorname{Pr}\left(y_{i j} \mid x_{i j}, \delta_{i j}\right)=\frac{e^{-\ln \left(\widehat{y_{\imath \jmath}}\right)} \ln \left(\widehat{y_{\imath j}}\right)^{y_{i j}}}{y_{i j} !} \quad$ For $\forall j=1, \ldots, 9$

Testing for over-dispersion in each of the models $\left(\mathrm{H}_{0}: \delta=1\right)$, the results suggest that the model under-fits the amount of dispersion in lobbying for all categories. Therefore it is appropriate to adopt the negative binomial model specification. However, several categories contained a significant number of zero counts. This necessitated the use of a zero inflated negative binomial specification, where the count outcome is weighted by the probability of that count being zero. ${ }^{8}$ The first model specification measures responses for each of the nine interest categories.

The second and third model specifications include all explanatory variables except for party groups, but are constrained respectively by membership of the EPP ( ${ }^{\text {nd }}$ model) and PES ( $3^{\text {rd }}$ model). This enables the effect of interest group lobbying of non-natural allies (and allies) to be assessed given that of the three dominant party groups, the EPP and PES occupy the most clearly contrasting positions on the dominant left/right political dimension. This distinction is replicated amongst the population of interest groups through the simplifying assumption that the five producer interests (agriculture, industry, transport, trade, and banking \& insurance) are likely to be allied more closely to the EPP, and are therefore nonnatural allies of the PES. This logic is then applied to the four civil societal interests (environment, human rights, gender, and consumer interests), with the expectation that their interests are more closely aligned with the PES.

\footnotetext{
${ }^{8}$ To ascertain the appropriate model, a Vuong test was used to compare the zero inflated negative binomial with the negative binomial baseline specification (see Long and Freese 2006 and Greene 1994).
} 


\section{Results}

This section assesses the extent to which the theoretical ideas stand up to scrutiny. The first step is to consider the hypotheses that explicitly relate to party groups. This is followed by an evaluation of the contextual expectations, which define the scope and relevance of the theory.

\section{Party group lobbying}

The initial hypothesis, that MEPs from the three dominant party groups are lobbied more often than members from other party families $\left(H_{1}\right)$, is assessed through the first model specification (Table 1). Looking first at the EPP variable (all significant at 0.1 level), the results indicate that party members are more likely to be lobbied than non-members by between $33.2 \%$ (agriculture \& fisheries groups) and $121.7 \%$ (trade \& commerce associations), when holding all other variables constant. ${ }^{9}$ A similar pattern is reported for the PES, with significant results found for eight of the nine categories of interest groups. The expected increase in reported lobbying contacts ranges from $40 \%$ (consumer groups) to $90 \%$ (transport groups). This effect is also closely replicated for the liberals (ALDE). Again significant results are found for eight of the nine categories of interest groups, indicating an increase in lobbying of party members ranging from $30.6 \%$ (consumer groups) to $214.2 \%$ (human rights groups).

These results lend considerable support to the theory, but what had not been anticipated is the strong focal point provided by the Green Party for environmental, consumer and agriculture/fisheries lobbyists. Interestingly, these results suggest that in the policy areas where the Green Party receives significant lobbying attention, the PES appears to be somewhat less favoured compared to other policy areas. This may be indicative of a

\footnotetext{
${ }^{9}$ The percentage figures, as reported in models 1,2 and 3 , are derived from exponential ${ }^{\beta}$. Hence for agriculture and fishing a factor change of $1.332=33.2$ percentage points, holding all other variables constant.
} 
reallocation of the portion of lobbying attention that is directed to 'friendly' left of centre parties.

\section{--- Table 1 about here ---}

To test the hypothesis that the frequency of MEP interactions with groups representing either civil society or producer interests will be similar for members of both the EPP and PES $\left(\mathrm{H}_{2}\right)$, the predicted counts (contacts) for the two party groups are assessed across all 9 categories of interest groups. The results are shown in Table 2; with committee membership, participation and parliament set to their mean value; rapporteurship to 0 , left/right self-placement to 5 , and country values set to Germany. ${ }^{10}$ The initial impression is that the relative party values for each category of interest group are broadly comparable, which is line with the expectation. More specifically, when comparing each pair of predicted counts we find that all confidence intervals overlap at the $95 \%$ level, enabling the null hypothesis to be rejected. It is also interesting to note that in 3 of the 4 instances (out of 18) where the predicted counts fall outside the opposing confidence interval we observe higher levels of unfriendly lobbying than friendly. Indeed the results give the impression of a fluid lobbying environment with PES lobbying likely to be higher than for the EPP in 2 of the 4 categories of producer interest, with the converse true for 3 of the 4 categories of civil society.

\section{--- Table 2 about here ---}

\footnotetext{
${ }^{10}$ There is no substantive difference to the predicted count result when the model is run without controls.
} 
An alternative perspective is provided through interviews with 80 interest groups representing both civil society and producer interests. Interviewees were asked to consider the number of policy related contacts that they have had with the three largest party groups, and then allocate a percentage to each. The results, in respect to the EPP and PES, are presented in Table 3. Although less convincing than those for the much larger sample of MEP reported contacts they nevertheless suggests that lobbying of unfriendly party groups is only $20 \%$ less common than lobbying of friendly groups, which is a long way from Baumgartner and Leech's (2002) assertion that this activity hardly ever happens.

\section{--- Table 3 about here ---}

It is also interesting to note, with reference to Model 1 (Table 1), that for each party group, the average increase in lobbying contacts for both producer and civil society interests turns out to be broadly comparable i.e. for the EPP: $70.3 \%$ / 78.4\%; and for the PES: $53.3 \%$ / $55.7 \%$. This indicates that the decision to lobby large party groups may be less constrained by ideology than the decision of which individual party member to lobby. This is illustrated in Figure 1, which shows the predicted counts for two categories of interests (business and civil society). Through the left/right self-placement scores (x-axis), the intensity of banking/insurance lobbying is shown to increase as MEPs move away from the left side of the ideological spectrum. The mirror-image of this effect can be observed for consumer groups. ${ }^{11}$ Interestingly, although the theory provides no expectation for lobbying within supportive party groups the same ideological bias is observable.

\footnotetext{
${ }^{11}$ These results also make it clear that the observable behaviour is not driven by a central lobbying tendency.
} 


\section{--- Figure 1 about here ---}

This provides some confidence to assess the final party group hypothesis that when interest groups attempt to influence dominant party groups that are naturally less supportive, they lobby those members with relatively close policy preferences $\left(H_{3}\right)$. This expectation is assessed with the aid of models $2 \& 3$ (Table 4). Here the results for each independent variable (interest category) relate only to members of the corresponding naturally less supportive party group. Hence the lobbying activities of civil society interests (4 categories) are reported for members of the EPP (model 2), whereas the lobbying activities of producer interests (5 categories) are reported for members of the PES (model 3). Two approaches are taken to assess this hypothesis.

\section{--- Table 4 about here ---}

Initially the effect of ideology within party group is assessed by means of the variable measuring MEPs' left/right self-placement score. The results for all nine committees are significant and in the anticipated party contingent direction. As such, holding all other variables constant, a 1 place move to the right in an EPP member's left/right self-placement score (range 1-10) is associated with a decrease in lobbying by civil societal interest of between $19.3 \%$ (consumer groups) and $33.9 \%$ (human rights groups). In line with expectations, the inverse effect is observable for the relationship between PES members and producer interest. Here the percentage change in producer interest lobbying associated with a 
1 point move to the right, ranges from $18.1 \%$ (agriculture \& fisheries groups) to $67.5 \%$ (banking \& insurance groups). The predicted counts for two categories of non-naturally allied interest are graphed in Figure 2.

\section{--- Figure 2 about here ---}

The high level of support found for hypothesis $\mathrm{H}_{3}$ on the party contingent left/right ideological dimension is also found to hold for an alternative measure: policy opinion(s). In all, five policy opinion variables are matched to five of the 9 interest group contact variables and are again tested through models $2 \& 3$ (Table 4). Here EPP members' opinions on civil societal issues are assessed (environmental, discrimination and refugee), along with PES members positions with respect to producer interests (agriculture and research \& development). The results for all five party contingent policy opinion variables were found to be significant and in the anticipated direction. That is to say, as the self-defined policy score of members of a relatively unfriendly large party group increases, i.e. their desire for more of the related policy decreases; they are less likely to be lobbied by associated interests. For example, the likely effect of an EPP member's one unit decrease in support for environmental protection standards (1-5 scale) is to decrease environmental groups' lobbying by $27.5 \%$, holding all other variables constant. An effect of similar magnitude is observable for a PES member's position on agricultural support with respect to lobbying by agricultural (and fishing) interests.

\section{Committee membership and participation}

Given that the EP's legislative committees have progressively increased their hold on policy making during the post-Amsterdam period of this analysis, it is vital to understand 
whether interest group behaviour reflects this shift in political power. If it can be shown that Interest groups are more likely to lobby MEPs that are members of a policy relevant committee than non-members $\left(H_{4}\right)$, and this finding holds within the analysis (models) presented thus far, then the theory of party group lobbying will be equally applicable within the EP's strong committee system.

Preliminary evidence for this expectation is offered in Figure 2 (above), which distinguishes between committee members and other MEPs, but a full assessment is made with reference to the committee membership dummy variable reported in model 1 (Table 1). Here the coefficients for all 9 committees are in the expected direction, and significant at the .01 level. This can be interpreted as, for example, the effect of committee membership in the committee with responsibility for consumer policy is to increase the expected number of consumer group lobbying contacts by $176.2(\%)$, holding all other variables constant. These encouraging findings also hold for interest group lobbying of large party groups that are nonnatural allies, as shown in models $2 \& 3$ (Table 4) with reference to the same committee membership variable.

The final expectation is that Interest groups are more likely to lobby MEPs that are active legislators $\left(H_{5}\right)$. Support for this hypothesis would further imbed the theory within the wider legislative literature, whilst providing a further insight in to how lobbyists differentiate between legislators, whereas a null result would challenge a key theoretical assumption that lobbyists are instrumental in their policy-seeking actions.

To make an evaluation the initial step is to assess the variable participation through the first model (Table 1). Here support for the hypotheses is found from seven of the nine interest groupings at the .1 level of significance or above. For a $1 \%$ increase in a MEPs attendance at roll-call votes, their likelihood of being lobbied increases by between $0.5 \%$ and $2.4 \%$. This level of increase is substantial when put in the context of the $12 \%$ to $100 \%$ range 
in MEP's level of attendance (mean = 80.2). Moreover, this finding also holds for the majority of interest categories when lobbying non-natural allies (models $2 \& 3$ ).

An alternative 'within committee' assessment is made through the explanatory variable rapporteur, which captures the most clearly identifiable act of participation. The results presented in model 1 (Table 1) show that seven of the nine committees are significant at the .1 level and in the direction anticipated, offering further support to the hypothesis. Holding all other variables constant the effect of each report that a committee member writes is to increase the expected number of lobbying contacts by a policy relevant interest group by between $13.1 \%$ (environmental groups) and 100.6\% (women's organisations). However, the results for lobbying a rapporteur that is a non-natural ally (models $2 \& 3$ ) are less convincing. Although, eight of the nine categories are in the anticipated direction, just four are at a sufficient level of significance ( 0.1 or above). The predicted counts for $\mathrm{H}_{4}$ and $\mathrm{H}_{5}$ are projected in Figure 3, for two categories of interest group lobbying.

\section{--- Figure 3 about here ---}

\section{Discussion}

This article establishes that interest groups that are active in the EP are policy-seekers with a highly nuanced grasp on the decision-making process. As a consequence, they identify that membership of any given party group or legislative committee will contribute to the differences in legislative influence between MEPs, and that within these memberships the distribution of influence is unevenly distributed. In addition, interest groups are able to assess MEPs' relative responsiveness to their policy position, as well as recognise and respond to 
the fluidity of voting coalitions. This knowledge amounts to a formidable array of strategic considerations.

Fundamental to the explanation is the atypical nature of vote-winning coalitions in the EP, which can and frequently do exclude one of the two largest party families. This situation occurs as a consequence of an institutional design that has at its heart a parliament with no government to support, and in which to date no party has achieved an overall majority of seats. As a result, it is difficult for lobbyists to predict which leading party family will be on the winning side of any given vote. This matters because if an interest group receives even very limited support from a winning coalition it may well be an improvement on receiving strong support from a party group that is excluded from the negotiating table. As such, in the absence of a voting equilibrium, interest groups choose to 'hedge their bets'.

This explanation has benefitted from an analytical approach that synthesises theoretical expectations with some of what we already know about the relative influence of MEPs. The analysis adds traction to Hall and Waymen's (1990) somewhat out of favour finding that in addition to organised interests expending resources persuading influential legislators within a friendly party to mobilise, there is a compelling reason to also persuade influential members of unfriendly party to desist from mobilising even if this latter activity is less effective. This is because the likelihood of persuading an influential member of an unfriendly party to refrain from actively participating is surely higher if they are at least relatively friendly.

Finally, the findings presented may well have implications for interest group behaviour in national parliaments, although here a different pattern of lobbying is anticipated. The key distinction is that in the national setting winning coalitions are generally stable owing to the presence of a permanent governing majority. Therefore, it should follow that interest groups for whom at least one governing party is an ally will have little or no incentive 
to lobby opposition parties. In contrast those interest groups that are aligned with a party in opposition will have a strong incentive to build relationships with governing parties. Therefore in the national context an asymmetric version of that shown for the EP is anticipated, one that flips in line with clear changes in government and opposition.

\section{Bibliography}

Allern, E. H. (2010) Political parties and interest groups in Norway (Colchester: ECPR Press).

Attinà, F. (1990) 'The Voting Behaviour of the European Parliament Members and the Problem of Europarties', European Journal of Political Research, Vol.18, No.3: 55779.

Baumgartner, F. R. and Leech, B. L. (1996) 'The Multiple Ambiguities of 'Counteractive Lobbying', American Journal of Political Science, Vol.40, No.2: 521-42.

Bouwen, P. (2004) 'The Logic of Access to the European Parliament: Business Lobbying in the Committee on Economic and Monetary Affairs', Journal of Common Market Studies, Vol.42, No.3: 473-95.

Costello, R. and Thomson, R. (2010) 'The Policy Impact of Leadership in Committees: Rapporteurs' Influence on the European Parliament's Opinions', European Union Politics, Vol.11, No.2: 219-40.

Crombez, C. (2001) 'The Treaty of Amsterdam and the Co-decision Procedure', In Schneider, G. and Aspinwall, M. (eds) The Rules of Integration: Institutional Approaches to the Study of Europe (Manchester: Manchester University Press) pp.101-122.

Crombez, C. (2002) 'Information, Lobbying and the Legislative Process in the European Union', European Union Politics, Vol.3, No.1: 7-32. 
Duverger, M. (1954) Political parties: Their organization and activity in the modern state, (London, Methuen).

Eising, R. (2007) 'Institutional Context, Organizsational Resources and Strategic Choices: Explaining Interest Group Access in the European Union', European Union Politics, Vol.8, No.3: 329-362.

Farrell, D., Hix. S. and Scully, R. (2011) ‘EPRG MEP Survey Dataset: 2011 Release.

Farrell, H. and Héritier, A. (2003) 'Formal and Informal Institutions Under Codecision: Continuous Constitution-Building in Europe', Governance, Vol.16, No.4: 577-600.

Greene, W. H. (1994) 'Accounting for Excess Zeros and Sample Selection in Poisson and Negative Binominal Regression Models', Stern School of Business, New York University, Department of Economics, Working Paper no.94-10.

Häge, F. M. and Kaeding, M. (2007) 'Reconsidering the European Parliament's Legislative Influence: Formal vs. Informal Procedures', European Integration, Vol.29, No.3: $341-361$.

Hall, R. L. and Waymen, F. W. (1990) 'Buying Time: Moneyed Interests and the Mobilzation of Bias in Congressional Committees'. American Political Science Review, Vol.84, No.3: 797-820.

Héritier, A. (2007) Explaining Institutional Change in Europe, (New York: Oxford University Press).

Hix, S. and Høyland, B (2011) The Political System of the European Union, (Basingstoke: Palgrave McMillan).

Hix, S. and Lord, C. (1997) Political Parties in the European Parliament, (London: Palgrave).

Hix, S., Noury, A. and Roland, G. (2006) 'Dimensions of Politics in the European Parliament', American Journal of Political Science, Vol.50, No.2: 494-511. 
Hix, S, Noury, A. and Roland, G (2007) Democratic Politics in the European Parliament, (Cambridge: Cambridge University Press).

Hix, S. and Noury, A. (2009) 'After Enlargement: Voting Patterns in the Sixth European Parliament', Legislative Quarterly, Vol.34, No.2: 159-74.

Hix, S., Scully, R. and Farrell, D. (2011) National or European Parliaments? Evidence from a New Survey of the Members of the European Parliament. Available at $<<$ http://www2.lse.ac.uk/government/research/resgroups/EPRG/pdf/Hix-ScullyFarrell.pdf $>>$.

Hojnacki, M. and Kimball, D. C. (1998) 'Organized Interests and the Decision of Whom to Lobby in Congress', The American Political Science Review, Vol.92, No.4: 775-90.

Høyland, B., Sircar, I. and Hix, S. (2009) 'An Automated Database of the European Parliament', European Union Politics, Vol.10, No.1: 143-52.

Katz, R. S. and Mair, P. (1995) 'Changing Models of Party Organiszation and Party Democracy'. Party Politics, Vol.1: 5-28.

Kadasheva, R. (2009), 'The Power to Delay: The European Parliament's Influence in the Consultation Procedure', Journal of Common Market Studies, Vol.47, No.2: 385-409.

Kohler-Koch, B. (1998) 'Organised Interests in the E.U. and the European Parliament.' In Claeys, P.H., Gobin, C. and Winard, P. (eds), Lobbying, Pluralism and European Integrations (European Interuniversity Press).

Kollman, K. (1997) 'Inviting friends to lobby: Interest groups, ideological bias, and Congressional Committees', American Journal of Political Science, Vol.4, No.2: 51944.

Kreppel, A (2002) The European Parliament and Supranational Party System: A Study in Institutional Development (Cambridge: Cambridge University Press). 
Long, S. J. and Freese, J. (2006) Regression Models for Categorical and Limited Dependent Variables Using Stata (College Station: Stata Press).

Mahoney, C. (2008) Brussels Versus the Beltway: Advocacy in the United States and the European Union (Washington D.C. Georgetown University Press).

Marshall, D. (2010) 'Who to Lobby and When: Institutional determinants of Interest Group Strategies in European Parliament Committees'. European Union Politics, Vol.11, No.4: 553-575.

McElroy, G. (2006) 'Committee Representation in the European Parliament', European Union Politics, Vol.7, No.1: 5-29.

Otjes, S. and Rasmussen, A. (2013) Interest Group - Party Collaboration in Multi-Party Democracies: Party System Dynamics and the effect of Power \& Ideology. Paper presented at the annual conference of the European Consortium for Political Research (ECPR), in Bordeaux, September 4-7, 2013.

Parker, G. R. (2004) Self-Policing in Politics: The Political Economy of Reputational Controls on Politicians (Princeton: Princeton University Press).

Quinn, T. (2010) 'New Labour and the trade unions in Britain'. Journal of Elections, Public Opinion \& Parties, Vol.20: 357-380.

Rasmussen, A. and Lindeboom, G. J. (2013) 'Interest group-party linkage in the twenty-first century: Evidence from Denmark, the Netherlands and the United Kingdom', European Journal of Political Research, Vol.52: 264-289.

Raunio, T. (1997) The European Perspective: Transnational Party Groups in the 1989-1994 European Parliament (London: Ashgate).

Ringe, N. (2010) Who Decides, And How? Preferences, Uncertainty, and Policy Choice in The European Parliament (Oxford: Oxford University Press). 
Thomas, C. S. (ed) (2001) Political parties and interest groups: Shaping democratic governance. Boulder, CO: Lynne Riener.

Wessels, B. (1999) 'European Parliament and Interest Groups.' In Katz, R. S and Wessels, B. (eds) The European Parliament, the National Parliaments; and European Integration (Oxford: Oxford University Press).

Yordanova, N. (2009) 'The Rationale behind Committee Assignment in the European Parliament', European Union Politics, Vol.10, No.2: 253-80.

Yoshinaka, A., McElroy, G. and Bowler, S. (2010) 'The Appointment of Rapporteurs in the European Parliament', Legislative Studies Quarterly, Vol.35, No.4: 457-486. 
Figure 1 Predicted lobbying counts across party membership
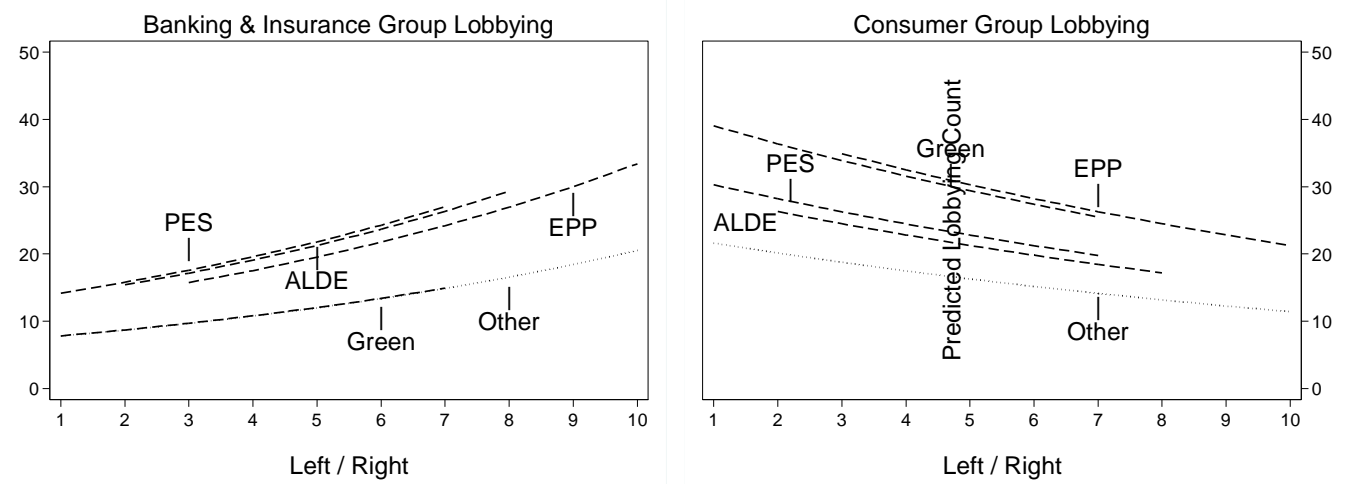

Note: predicted count is for a corresponding committee member, non-rapporteur, with country values set to Germany and all other values held at their mean

Figure 2 Predicted effects for lobbying unnatural allies and policy preferences
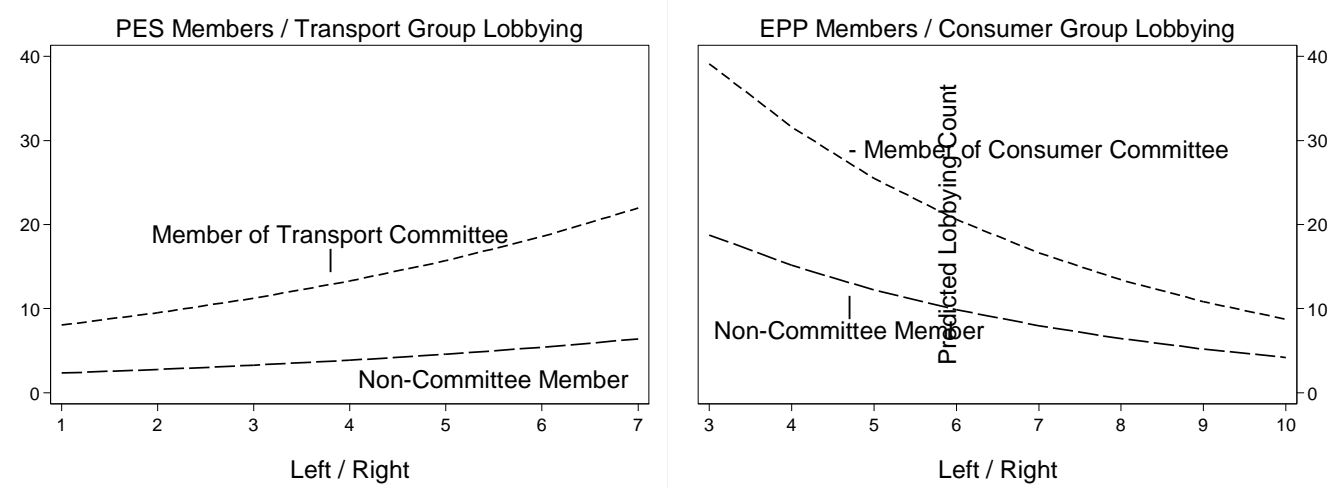

Note: Based respectively on models $1 \& 2$; country values set to Germany; rapporteur at zero; all others held at their means.

Figure 3 Predicted lobbying counts for rapporteurs, relevant committee membership, across participation in the plenary
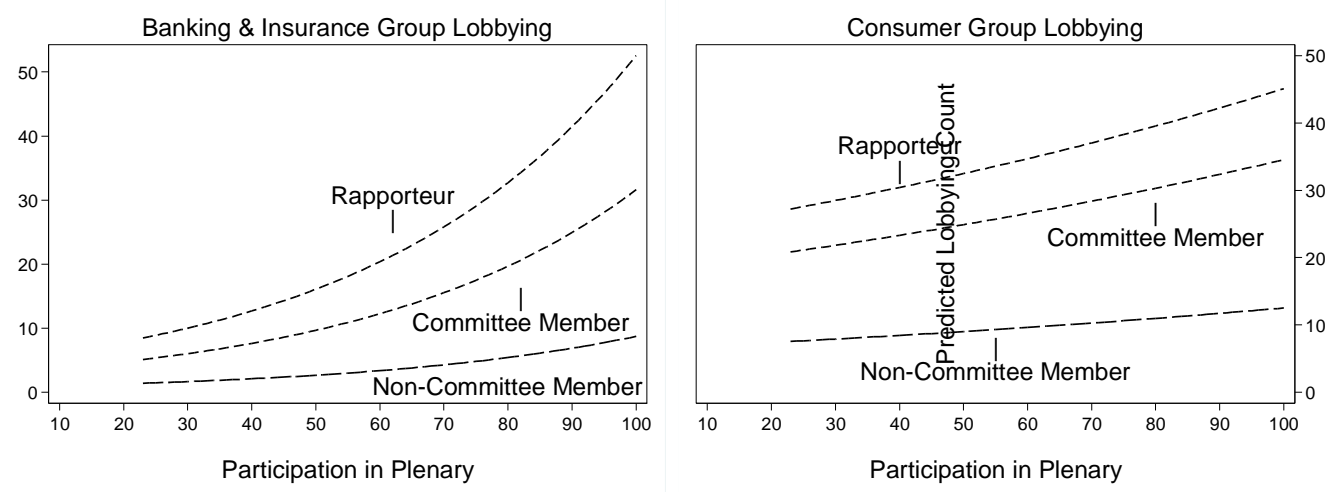

Note: The values for rapporteur are set to their median, EPP as party group, with Germany as large country. All other values are set to their mean. Derived from model 1. 
Table 1 Model 1: Explaining Interest Group Contacts with MEPs

\begin{tabular}{|c|c|c|c|c|c|c|c|c|c|}
\hline Independent Variables & $\begin{array}{l}\text { Environ } \\
\text { Groups }\end{array}$ & $\begin{array}{l}\text { Human } \\
\text { rights } \\
\text { Groups }\end{array}$ & $\begin{array}{l}\text { Women's } \\
\text { Organis- } \\
\text { ations }\end{array}$ & $\begin{array}{l}\text { Consumer } \\
\text { Groups }\end{array}$ & $\begin{array}{l}\text { Agriculture } \\
\text { Fisheries } \\
\text { Groups }\end{array}$ & $\begin{array}{l}\text { Banking \& } \\
\text { Insurance } \\
\text { Groups }\end{array}$ & $\begin{array}{l}\text { Industrial } \\
\text { Organis- } \\
\text { ations }\end{array}$ & $\begin{array}{l}\text { Trade \& } \\
\text { Commerce } \\
\text { Associations }\end{array}$ & $\begin{array}{l}\text { Transport } \\
\text { Groups }\end{array}$ \\
\hline & \multicolumn{4}{|c|}{ Civil Societal Interests } & \multicolumn{5}{|c|}{ Producer Interests } \\
\hline \multirow{2}{*}{ Specification } & & & & & Zero Inflated & & Zero Inflated & & \\
\hline & NBREG & NBREG & NBREG & NBREG & NBREG & NBREG & NBREG & NBREG & NBREG \\
\hline \multirow[t]{3}{*}{ EPP } & $0.48 * * *$ & $0.71 * * *$ & $0.49 * *$ & $0.62 * * *$ & $0.29 *$ & $0.49 * *$ & $0.43^{* *}$ & $0.80 * * *$ & $0.59 * * *$ \\
\hline & $61.2 \%$ & $102.8 \%$ & $63.6 \%$ & $86 \%$ & $33.2 \%$ & $62.8 \%$ & $54.4 \%$ & $121.7 \%$ & $80.5 \%$ \\
\hline & $(0.147)$ & $(0.19)$ & $(0.204)$ & $(0.142)$ & $(0.164)$ & $(0.180)$ & $(0.153)$ & $(0.160)$ & $(0.183)$ \\
\hline \multirow[t]{3}{*}{ PES } & 0.17 & $0.35^{*}$ & $0.62 * *$ & $0.34 * *$ & $0.49 * *$ & $0.60 * *$ & $0.37 * *$ & $0.57 * * *$ & $0.65^{* * *}$ \\
\hline & $18 \%$ & $42.2 \%$ & $85.1 \%$ & $40 \%$ & $62.5 \%$ & $81.8 \%$ & $45.3 \%$ & $76.1 \%$ & $90.6 \%$ \\
\hline & $(0.151)$ & $(0.194)$ & $(0.222)$ & $(0.150)$ & $(0.178)$ & $(0.189)$ & $(0.156)$ & $(0.168)$ & $(0.189)$ \\
\hline \multirow[t]{3}{*}{ ALDE } & $0.41 * *$ & $1.15^{* * *}$ & $0.45^{*}$ & $0.27 *$ & $0.44 * *$ & $0.57 * *$ & $0.39 * *$ & $0.55 * *$ & 0.31 \\
\hline & $51 \%$ & $214.2 \%$ & $56.1 \%$ & $30.6 \%$ & $54.7 \%$ & $77.2 \%$ & $47.4 \%$ & $73.2 \%$ & $36.4 \%$ \\
\hline & $(0.165)$ & $(0.220)$ & $(0.232)$ & $(0.160)$ & $(0.190)$ & $(0.203)$ & $(0.166)$ & $(0.180)$ & $(0.205)$ \\
\hline \multirow[t]{3}{*}{ Greens } & $0.81 * * *$ & 0.54 & 0.30 & $0.59 * *$ & $0.59 * *$ & 0.00 & -0.01 & -0.21 & 0.28 \\
\hline & $123.7 \%$ & $72.3 \%$ & $35.5 \%$ & $80.5 \%$ & $79.8 \%$ & $0 \%$ & $-1.2 \%$ & $18.5 \%$ & $31.9 \%$ \\
\hline & $(0.215)$ & $(0.314)$ & $(0.298)$ & $(0.209)$ & $(0.277)$ & $(0.277)$ & $(0.248)$ & $(0.25)$ & $(0.275)$ \\
\hline \multirow[t]{3}{*}{ Left/Right Self-Placement } & -0.11 & $-0.25 * * *$ & $-0.08 *$ & $-0.07 * *$ & 0.03 & $0.11^{* *}$ & $0.60 *$ & $0.7 * *$ & $0.07 *$ \\
\hline & $-10.1 \%$ & $-22 \%$ & $-7.5 \%$ & -6.8 & $3 \%$ & $11.3 \%$ & $6.1 \%$ & $7 \%$ & $7.7 \%$ \\
\hline & $(0.032)$ & $(0.038)$ & $(0.048)$ & $(0.310)$ & $(0.035)$ & $(0.04)$ & $(0.032)$ & $(0.034)$ & $(0.041)$ \\
\hline \multirow[t]{3}{*}{ Policy Opinion } & $-0.26^{* * * *}$ & $-0.16^{* *}$ & $-0.35 * * *$ & $\mathrm{n} / \mathrm{a}$ & $-0.34^{*}$ & $\mathrm{n} / \mathrm{a}$ & $-0.26^{* * * *}$ & $\mathrm{n} / \mathrm{a}$ & $\mathrm{n} / \mathrm{a}$ \\
\hline & $-13 \%$ & $-14.4 \%$ & $-29.2 \%$ & $\mathrm{n} / \mathrm{a}$ & $-28.8 \%$ & $\mathrm{n} / \mathrm{a}$ & $-23.3 \%$ & $\mathrm{n} / \mathrm{a}$ & $\mathrm{n} / \mathrm{a}$ \\
\hline & $(0.053)$ & $(0.057)$ & $(0.066)$ & $\mathrm{n} / \mathrm{a}$ & $(0.052)$ & $\mathrm{n} / \mathrm{a}$ & $(0.051)$ & $\mathrm{n} / \mathrm{a}$ & $\mathrm{n} / \mathrm{a}$ \\
\hline \multirow[t]{3}{*}{ Committee membership } & $1.24 * * *$ & $1.29 * * *$ & $1.98 * * *$ & $1.02 * * *$ & $1.49 * * *$ & $1.29 * * *$ & $0.97 * * *$ & $1.50 * * *$ & $1.42 * * *$ \\
\hline & $246 \%$ & $262.4 \%$ & $623.7 \%$ & $176.2 \%$ & $344.2 \%$ & $263 \%$ & $164.4 \%$ & $347.8 \%$ & $314.3 \%$ \\
\hline & $(0.123)$ & $(0.161)$ & $(0.264)$ & $(0.178)$ & $(0.153)$ & $(0.279)$ & $(0.133)$ & $(0.214)$ & $(0.227)$ \\
\hline \multirow[t]{3}{*}{ Participation } & $0.02 * * *$ & $0.01 * *$ & 0.00 & $0.01 * *$ & $0.01^{* *}$ & $0.02 * * *$ & $0.01 *$ & 0.01 & $0.01 * *$ \\
\hline & $1.5 \%$ & $0.9 \%$ & $0.3 \%$ & $0.7 \%$ & $0.9 \%$ & $2.4 \%$ & $0.5 \%$ & $0.6 \%$ & $1.1 \%$ \\
\hline & $(0.002)$ & $(0.004)$ & $(0.00)$ & $(0.003)$ & $(0.003)$ & $(0.004)$ & $(0.003)$ & $(0.004)$ & $(0.004)$ \\
\hline \multirow[t]{3}{*}{ Rapporteur } & $0.12 * *$ & $0.22 * *$ & $0.70^{*}$ & $0.13^{* *}$ & -0.03 & $0.25^{* *} *$ & $0.24 * *$ & 0.14 & $0.43^{* * *}$ \\
\hline & $13.1 \%$ & $24.8 \%$ & $100.6 \%$ & $14.2 \%$ & $-3.2 \%$ & $28.9 \%$ & $26.9 \%$ & $15.6 \%$ & $54.1 \%$ \\
\hline & (0.059) & $(0.093)$ & $(0.381)$ & $(0.064)$ & $(0.113)$ & $(0.103)$ & $(0.106)$ & $(0.135)$ & $(0.134)$ \\
\hline \multirow[t]{2}{*}{ Parliament: compare 6th/5th } & 0.12 & 0.12 & $\mathrm{n} / \mathrm{a}$ & -0.11 & -0.13 & -0.13 & -0.01 & $0.24 * *$ & 0.21 \\
\hline & $(0.109)$ & $(0.141)$ & $\mathrm{n} / \mathrm{a}$ & $(0.106)$ & $(0.125)$ & $(0.135)$ & $(0.110)$ & $(0.120)$ & $(0.137)$ \\
\hline Parliament: compare 7 th $/ 5$ th & 0.04 & -0.01 & $-0.23^{*}$ & 0.03 & -0.19 & -0.04 & -0.3 & $0.28 * *$ & 0.11 \\
\hline [Note: Women org: compare 7th/6th] & $(0.119)$ & $(0.158)$ & $(0.131)$ & $(0.118)$ & $(0.138)$ & $(0.146)$ & $(0.119)$ & $(0.132)$ & $(0.153)$ \\
\hline \multirow[t]{2}{*}{ Germany } & 0.05 & -0.20 & -0.29 & 0.04 & 0.22 & 0.17 & 0.21 & $0.42 * *$ & -0.08 \\
\hline & $(0.141)$ & $(0.179)$ & $(0.204)$ & $(0.136)$ & $(0.172)$ & $(0.173)$ & $(0.144)$ & $(0.154)$ & $(0.183)$ \\
\hline \multirow[t]{2}{*}{ France } & 0.09 & 0.17 & 0.08 & -0.21 & 0.16 & $0.12 *$ & -0.19 & 0.06 & 0.07 \\
\hline & $(0.165)$ & $(0.212)$ & $(0.230)$ & $(0.154)$ & $(0.186)$ & $(0.207)$ & $(0.165)$ & $(0.179)$ & 0.201 \\
\hline \multirow[t]{2}{*}{ Italy } & $0.3^{* *}$ & 0.24 & $0.55^{* *}$ & $0.57 * * *$ & 0.14 & $0.52 * *$ & $0.38 * *$ & $0.32 * *$ & $0.77 * * *$ \\
\hline & $(0.146)$ & $(0.19)$ & $(0.201)$ & $(0.142)$ & $(0.165)$ & $(0.180)$ & $0.143)$ & $(0.162)$ & $(0.183)$ \\
\hline \multirow[t]{2}{*}{ United Kingdom } & $0.50 * * *$ & $0.58^{* *}$ & 0.24 & $0.42 * *$ & $0.50 * * *$ & $0.34 * *$ & $0.47 * * *$ & $0.53 * * *$ & $0.63^{* * *}$ \\
\hline & $(0.141)$ & $(0.188)$ & $(0.216)$ & $(0.137)$ & $(0.158)$ & $(0.170)$ & $(0.139)$ & $(0.154)$ & $(0.175)$ \\
\hline Number of Observations & 560 & 471 & 358 & 578 & 543 & 583 & 552 & 572 & 577 \\
\hline \multirow{2}{*}{$\begin{array}{l}\text { Test for overdispersion } \chi^{2}= \\
\text { Vuong Statistic (Zero inflated }\end{array}$} & $5120.02 *$ & $* 2909.34 * *$ & $* 2207.42 * *$ & $* 4417.28 * *$ & $3611.19 * * *$ & $* 3712.2 * * *$ & $4735.49^{* *}:$ & $* 4470.08 * * *$ & $3811.82 * * *$ \\
\hline & d) $z=1.07$ & $\mathrm{z}=1.08$ & $\mathrm{z}=0.82$ & $\mathrm{z}=1.23$ & $\mathrm{z}=2.38 * *$ & $z=2.35$ & $\mathrm{z}=1.53^{*}$ & $z=1.56$ & $\mathrm{z}=2.02$ \\
\hline
\end{tabular}

Notes: ***significant at 0.01 level, **significant at 0.05 level, *significant at 0.1 level. Standard errors in parentheses. 
Table 2 Predicted Counts with Confidence Intervals for MEPs from the EPP \& PES across Interest Group Categories

\begin{tabular}{|c|c|c|c|}
\hline \multicolumn{2}{|l|}{ Independent Variable } & $\begin{array}{l}\text { Predicted } \\
\text { Contacts }\end{array}$ & $\begin{array}{l}\text { Confidence } \\
\text { Intervals } 95 \%\end{array}$ \\
\hline \multicolumn{4}{|c|}{ Environmental Groups: } \\
\hline & EPP member & 12.99 & $9.38,16.61$ \\
\hline & PES member & 9.58 & $6.72, \quad 12.43$ \\
\hline \multicolumn{4}{|c|}{ Human Rights Groups: } \\
\hline & EPP member & 5.4 & $3.77,7.05$ \\
\hline & PES member & 3.62 & $2.33,4.9$ \\
\hline \multicolumn{4}{|c|}{ Women's Organisations: } \\
\hline & EPP member & 5.58 & $3.40, \quad 7.75$ \\
\hline & PES member & 5.7 & $3.16,8.23$ \\
\hline \multicolumn{4}{|l|}{ Consumer Groups: } \\
\hline & EPP member & 13.39 & $9.82, \quad 16.96$ \\
\hline & PES member & 10.08 & $7.07, \quad 13.09$ \\
\hline \multicolumn{4}{|c|}{ Agriculture \& Fisheries Groups: } \\
\hline & EPP member & 7.6 & $5.18, \quad 10.00$ \\
\hline & PES member & 6.38 & $3.92,8.85$ \\
\hline \multicolumn{4}{|c|}{ Banking \& Insurance Groups: } \\
\hline & EPP member & 6.52 & $4.40,8.64$ \\
\hline & PES member & 7.28 & $4.50,10.06$ \\
\hline \multicolumn{4}{|c|}{ Industrial Organisations: } \\
\hline & EPP member & 15.04 & 11.11, 18.97 \\
\hline & PES member & 14.93 & $10.29, \quad 19.57$ \\
\hline \multicolumn{4}{|c|}{ Trade \& Commerce Associations: } \\
\hline & EPP member & 15.01 & $10.63, \quad 19.38$ \\
\hline & PES member & 11.92 & $7.96, \quad 15.87$ \\
\hline \multicolumn{4}{|l|}{ Transport Groups: } \\
\hline & EPP member & 5.9 & $3.89, \quad 7.90$ \\
\hline & PES member & 6.22 & $3.69, \quad 8.76$ \\
\hline
\end{tabular}

Table 3 Lobbying the EPP \& PES

\begin{tabular}{lcccc}
\hline & $\begin{array}{c}\text { Answers } \\
\text { received }\end{array}$ & EPP & PES & Difference \\
\hline Civil Society Interest Groups (NGOs) & 30 & $46 \%$ & $54 \%$ & $(-15 \%)$ \\
Businesses / Business Associations & 50 & $57 \%$ & $43 \%$ & $(-25 \%)$ \\
\hline Total & 80 & $100 \%$ & $100 \%$ & $20 \%$ \\
\hline
\end{tabular}


Table 4 Models 2 \& 3:

Explaining Interest Group Contacts with Party Groups that are Not Natural Allies

\begin{tabular}{|c|c|c|c|c|c|c|c|c|c|}
\hline Independent Variables & $\begin{array}{l}\text { Environ } \\
\text { Groups }\end{array}$ & $\begin{array}{l}\text { Human } \\
\text { rights } \\
\text { Groups }\end{array}$ & $\begin{array}{l}\text { Women's } \\
\text { Organis- } \\
\text { ations }\end{array}$ & $\begin{array}{l}\text { Consumer } \\
\text { Groups }\end{array}$ & $\begin{array}{l}\text { Agriculture } \\
\text { Fisheries } \\
\text { Groups }\end{array}$ & $\begin{array}{l}\text { Banking \& } \\
\text { Insurance } \\
\text { Groups }\end{array}$ & $\begin{array}{l}\text { Industrial } \\
\text { Organis- } \\
\text { ations }\end{array}$ & $\begin{array}{l}\text { Trade \& } \\
\text { Commerce } \\
\text { Associations }\end{array}$ & $\begin{array}{l}\text { Transport } \\
\text { Groups }\end{array}$ \\
\hline & & \multicolumn{3}{|l|}{ Model 2} & \multicolumn{5}{|c|}{ Model 3} \\
\hline & EPP Lobb & bying by $C i$ & vil Societal & Interests & & ES Lobbyin & g by Produc & rests & \\
\hline Specification & $\begin{array}{l}\text { Zero Inflated } \\
\text { NBREG }\end{array}$ & NBREG & NBREG & NBREG & $\begin{array}{l}\text { Zero Inflated } \\
\text { NBREG }\end{array}$ & NBREG & NBREG & NBREG & NBREG \\
\hline Left/Right Self-Placement & $\begin{array}{l}-0.23 * * * \\
-20.8 \% \\
(0.072)\end{array}$ & $\begin{array}{l}-0.41 * * * \\
-33.9 \% \\
(0.077)\end{array}$ & $\begin{array}{l}-0.29 * * * \\
-24.8 \% \\
(0.940)\end{array}$ & $\begin{array}{l}-0.21 * * * \\
-19.3 \% \\
(0.071)\end{array}$ & $\begin{array}{l}0.17 * \\
18.1 \% \\
(0.081)\end{array}$ & $\begin{array}{l}0.52 * * * \\
67.5 \% \\
(0.115)\end{array}$ & $\begin{array}{l}0.47 * * * \\
59.5 \% \\
(0.086)\end{array}$ & $\begin{array}{l}0.29 * * * \\
33.6 \% \\
(0.103)\end{array}$ & $\begin{array}{l}0.17^{*} \\
18.2 \% \\
(0.085)\end{array}$ \\
\hline Policy Opinion & $\begin{array}{l}-0.32 * * * \\
-27.5 \% \\
(0.087)\end{array}$ & $\begin{array}{l}-0.35 * * * \\
-29.8 \% \\
(0.083)\end{array}$ & $\begin{array}{l}-0.37 * * * \\
-30.7 \% \\
(0.097)\end{array}$ & $\begin{array}{l}\mathrm{n} / \mathrm{a} \\
\mathrm{n} / \mathrm{a} \\
\mathrm{n} / \mathrm{a}\end{array}$ & $\begin{array}{l}-0.31 * * * \\
-26.8 \\
(0.106)\end{array}$ & $\begin{array}{l}\mathrm{n} / \mathrm{a} \\
\mathrm{n} / \mathrm{a} \\
\mathrm{n} / \mathrm{a}\end{array}$ & $\begin{array}{l}-0.46^{* * * *} \\
-37 \% \\
(0.124)\end{array}$ & $\begin{array}{l}\mathrm{n} / \mathrm{a} \\
\mathrm{n} / \mathrm{a} \\
\mathrm{n} / \mathrm{a}\end{array}$ & $\begin{array}{l}\mathrm{n} / \mathrm{a} \\
\mathrm{n} / \mathrm{a} \\
\mathrm{n} / \mathrm{a}\end{array}$ \\
\hline Committee membership & $\begin{array}{l}1.00 * * * * \\
171.9 \% \\
(0.374)\end{array}$ & $\begin{array}{l}0.90 * * * \\
145.5 \% \\
(0.252)\end{array}$ & $\begin{array}{l}2.08 * * * \\
702.9 \% \\
(0.356)\end{array}$ & $\begin{array}{l}0.73 * * \\
108.4 \% \\
(0.352)\end{array}$ & $\begin{array}{l}1.47 * * * \\
336.70 \% \\
(0.318)\end{array}$ & $\begin{array}{l}1.33 * * * \\
279.1 \% \\
(0.510)\end{array}$ & $\begin{array}{l}1.07 * * * \\
191.2 \% \\
(0.249)\end{array}$ & $\begin{array}{l}1.29 * * * \\
261.80 \% \\
(0.459)\end{array}$ & $\begin{array}{l}1.23 * * \\
242.7 \% \\
(0.433)\end{array}$ \\
\hline Participation & $\begin{array}{l}0.01 * \\
1 \% \\
(0.006)\end{array}$ & $\begin{array}{l}0.01 * \\
1.3 \% \\
(0.007)\end{array}$ & $\begin{array}{l}-0.01 \\
-0.6 \\
(0.009)\end{array}$ & $\begin{array}{l}0.02 * * \\
1.6 \% \\
(0.006)\end{array}$ & $\begin{array}{l}0.01 * * \\
1.3 \% \\
(0.006)\end{array}$ & $\begin{array}{l}0.02 * * * \\
1.8 \% \\
(0.007)\end{array}$ & $\begin{array}{l}0.00 \\
0.2 \% \\
(0.005)\end{array}$ & $\begin{array}{l}0.01 \\
0.6 \% \\
(0.007)\end{array}$ & $\begin{array}{l}0.00 \\
0.2 \% \\
(0.007)\end{array}$ \\
\hline Rapporteur & $\begin{array}{l}0.12 \\
12.4 \% \\
(0.099)\end{array}$ & $\begin{array}{l}0.42 * * \\
51.9 \% \\
(0.165)\end{array}$ & $\begin{array}{l}0.30 \\
34.8 \% \\
(0.171)\end{array}$ & $\begin{array}{l}0.10^{*} \\
11 \% \\
(0.050)\end{array}$ & $\begin{array}{l}-0.13 \\
-12.2 \% \\
(0.135)\end{array}$ & $\begin{array}{l}0.22 * \\
24.3 \% \\
(0.121)\end{array}$ & $\begin{array}{l}0.11 \\
12.1 \% \\
(0.125)\end{array}$ & $\begin{array}{l}0.10 \\
10.2 \% \\
(0.186)\end{array}$ & $\begin{array}{l}0.65 * * \\
92.3 \% \\
(0.303)\end{array}$ \\
\hline Parliament: compare 6th/5th & $\begin{array}{l}0.44 * * \\
(0.188)\end{array}$ & $\begin{array}{l}0.61 * * * \\
(0.218)\end{array}$ & $\begin{array}{l}\mathrm{n} / \mathrm{a} \\
\mathrm{n} / \mathrm{a}\end{array}$ & $\begin{array}{l}-0.07 \\
(0.185)\end{array}$ & $\begin{array}{l}0.31 \\
(0.268)\end{array}$ & $\begin{array}{l}-0.27 \\
(0.235)\end{array}$ & $\begin{array}{l}-0.03 \\
(0.195)\end{array}$ & $\begin{array}{l}0.47 * * \\
(0.235)\end{array}$ & $\begin{array}{l}0.07 \\
(0.262)\end{array}$ \\
\hline $\begin{array}{l}\text { Parliament: compare } 7 \mathrm{th} / 5 \text { th } \\
\text { [Note: Women org: compare } 7 \mathrm{th} / 6 \mathrm{th}]\end{array}$ & $\begin{array}{l}0.27 \\
(0.209)\end{array}$ & $\begin{array}{l}0.30 \\
(0.257)\end{array}$ & $\begin{array}{l}0.51 * * \\
(0.218)\end{array}$ & $\begin{array}{l}0.16 \\
(0.209)\end{array}$ & $\begin{array}{l}0.16 \\
(0.271)\end{array}$ & $\begin{array}{l}-0.24 \\
(0.248)\end{array}$ & $\begin{array}{l}-0.01 \\
(0.209)\end{array}$ & $\begin{array}{l}0.29 \\
(0.244)\end{array}$ & $\begin{array}{l}0.33 \\
(0.292)\end{array}$ \\
\hline Germany & $\begin{array}{l}-0.04 \\
(0.204)\end{array}$ & $\begin{array}{l}-0.09 \\
(0.243)\end{array}$ & $\begin{array}{l}-0.72 * * \\
(0.307)\end{array}$ & $\begin{array}{l}-0.02 \\
(0.204)\end{array}$ & $\begin{array}{l}0.42 \\
(0.396)\end{array}$ & $\begin{array}{l}0.14 \\
(0.305)\end{array}$ & $\begin{array}{l}0.26 \\
(0.277)\end{array}$ & $\begin{array}{l}1.01 * * * \\
(0.312)\end{array}$ & $\begin{array}{l}-0.33 \\
(0.375)\end{array}$ \\
\hline France & $\begin{array}{l}0.21 \\
(0.333)\end{array}$ & $\begin{array}{l}0.28 \\
(0.373)\end{array}$ & $\begin{array}{l}0.22 \\
(0.424)\end{array}$ & $\begin{array}{l}0.44 \\
(0.332)\end{array}$ & $\begin{array}{l}0.40 \\
(0.298)\end{array}$ & $\begin{array}{l}-0.03 \\
(0.314)\end{array}$ & $\begin{array}{l}-0.17 \\
(0.248)\end{array}$ & $\begin{array}{l}0.57 * * \\
(0.290)\end{array}$ & $\begin{array}{l}0.24 \\
(0.341)\end{array}$ \\
\hline Italy & $\begin{array}{l}0.02 \\
(0.226)\end{array}$ & $\begin{array}{l}0.23 \\
(0.254)\end{array}$ & $\begin{array}{l}0.54 * \\
(0.303)\end{array}$ & $\begin{array}{l}0.72 * * * \\
(0.230)\end{array}$ & $\begin{array}{l}0.67 * * \\
(0.359)\end{array}$ & $\begin{array}{l}0.57 \\
(0.349)\end{array}$ & $\begin{array}{l}-0.12 \\
(0.291)\end{array}$ & $\begin{array}{l}0.66^{* * *} \\
(0.336)\end{array}$ & $\begin{array}{l}0.27 \\
(0.383)\end{array}$ \\
\hline United Kingdom & $\begin{array}{l}0.81 * * * \\
(0.268)\end{array}$ & $\begin{array}{l}1.27 * * * \\
(0.314)\end{array}$ & $\begin{array}{l}1.06 * * \\
(0.467)\end{array}$ & $\begin{array}{l}0.61 * * \\
(0.265)\end{array}$ & $\begin{array}{l}0.75^{* * *} \\
(0.325)\end{array}$ & $\begin{array}{l}0.16 \\
(0.318)\end{array}$ & $\begin{array}{l}0.63 * * \\
(0.253)\end{array}$ & $\begin{array}{l}0.93 * * * \\
(0.303)\end{array}$ & $\begin{array}{l}0.64^{*} \\
(0.354)\end{array}$ \\
\hline Number of Observations & 194 & 173 & 116 & 198 & 160 & 171 & 164 & 167 & 170 \\
\hline $\begin{array}{l}\text { Test for overdispersion: } \chi^{2}= \\
\text { Vuong Statistic (Zero inflated) }\end{array}$ & $\begin{array}{l}1518.65^{* * *} \\
\mathrm{z}=1.94 * *\end{array}$ & $\begin{array}{l}480.69^{* * * *} \\
z=0.78\end{array}$ & $\begin{array}{l}416.44^{* * * *} \\
\mathrm{z}=0.91\end{array}$ & $\begin{array}{l}1655.3^{* * * *} \\
\mathrm{z}=0.85\end{array}$ & $\begin{array}{l}1000.27 * * * \\
\mathrm{z}=1.64 *\end{array}$ & $\begin{array}{l}969.75^{* * *} \\
z=0.97\end{array}$ & $\begin{array}{l}946.66^{* * * *} \\
z=1.28\end{array}$ & $\begin{array}{l}959.73^{* * * *} \\
\mathrm{z}=1.02\end{array}$ & $\begin{array}{l}1157.47^{* * * *} \\
\mathrm{z}=0.87\end{array}$ \\
\hline
\end{tabular}

